\title{
Urban Transport of Passengers in Large Urban Agglomerations and Sustainable Development. Experience of Bucharest Municipality in Romania
}

\author{
Florina Bran ${ }^{1}$, professor PhD, Sorin Burlacu ${ }^{1}$, lecturer PhD, \\ Cristina Alpopi ${ }^{1}$, professor $\mathrm{PhD}$
}

\begin{abstract}
Urban transport of passengers is considered in Romania a priority of local communities. Thus, this service, together with four other services (water supply and sewerage, public lighting, sanitation and district heating), is subject to a special law, Law 51/2006, also called the Law on Community Utilities. In 2016 the public utility law was republished, amended and completed by Law 225. Why it was necessary to change and complete the law of public utilities and what role the urban public transport service has in the sustainable development of localities, are questions that we are trying to answer through our research. The proliferation of green transport modalities as well as technological progress have forced paradigm shifts in terms of mobility in large urban agglomerations. A comparative analysis of the public transport modalities in the large urban agglomerations comparable to Bucharest could not be made without considering the socio-economic and environmental factors. Sustainable development of urban transport will help to increase the quality of life for urban residents and regain the well-deserved position of urban transport as a public service of general interest.
\end{abstract}

Keywords: sustainable transport, sustainable development, Bucharest experience

\section{Introduction}

According to the Sustainable Urban Mobility Plan (PMUD) 2016-2030 for the Bucharest-Ilfov Region, "an efficient, integrated, sustainable and safe transport system (designed to promote the socially inclusive economic and territorial development and to ensure a high quality of life. "PMUD aims at fulfilling the vision of developing mobility by addressing the following strategic objectives:

I. Accessibility - Ensures that all citizens have transport options that allow them access to essential destinations and services;

II. Safety and Security - Improvement of safety and security in circulation;

III. Environment - Reduction of air and noise pollution, greenhouse gas emissions and energy consumption;

IV. Economic Efficiency - Improving the efficiency and cost-effectiveness of the transport of persons and goods;

V. Quality of the Urban Environment - Contributes to increasing the attractiveness and quality of the urban environment and to the design of an urban environment for the benefit of citizens, the economy and society in general. 
The pursuit of the proposed strategic objectives in the sustainable urban mobility plan (PMUD) and the identification of effective implementation measures are essential for increasing the quality of services in the Integrated Traffic Management System in Bucharest.

Among the social measures proposed in the Urban Mobility Plan, the project to improve accessibility for people with reduced mobility draws attention to the proposed targets, such as:

- Elimination of all obstacles mounted on sidewalks, pedestrian circulation planning and monitoring compliance with all provisions of Norm 51/2012 (Revision NP 051/2000). Examples: blooms, billboards, kiosks, etc.

- Accessing, as a first step, a primary network formed by the streets where public transport circulates (pavement, signage, intersections, refugees, etc.).

- Accessing a secondary street network connecting the primary network of institutions public and private interests of general interest (health, education, social services, culture, trade, office buildings, etc.)

- Accessibility of the public transport system and related stations (automated releases of tickets, signaling, access to stations, access to vehicles, vehicles, facilities etc.)

- Trip planning (maps, information, dedicated phone, etc.).

- Accessibility guide for public and private institutions (mandatory arrangements, recommendations, etc.).

Better accessibility is beneficial to the whole community, not only to people with disabilities, generating economic and social development and ensuring better integration of social categories at risk of isolation. Ensuring the inclusive accessibility of public space and public transport is an objective of PMUD and is a condition of social justice and equal opportunities for access to the city, public services and jobs without marginalization of people with reduced mobility, considering that an accessible public space is more comfortable, safe and attractive, being an indicator of increasing the quality of life.

In PMUD's optimal scenario are presented non-commercial benefits that can contribute to the social welfare of urban citizens. Applying the PMUD measures could help reduce travel time for public transport passengers as well as for drivers and passengers traveling by car or other categories of vehicles. Some of the measures proposed in PMUD presuppose the abandonment of the use of personal cars for public transport with the argument of saving operating costs and other costs by avoiding fatal accidents and injuries caused by road accidents, reducing NOx and particulate emissions, and avoiding climate change due to CO2 emissions.

\section{Research Goal}

The objective of our research is to present a comparative analysis of the main ways of organizing the public urban transport service in some of the cities of the world comparable to Bucharest in terms of population size and density, as well as to analyze the urban mobility plan proposed by the municipality in line with current technological challenges and taking into account the characteristics required for sustainable urban development. 


\section{Methodology}

The main research methods used were the documentary analysis of legislation in the field of mobility and public services of general interest in Romania, the realization of the knowledge stage and the simulation of the loading of the mobility plan with various transport capacities in order to determine the levels of pollution and their framing within the limits admitted, according to international standards regarding the sustainable and healthy development of the city.

\section{State of the Art}

More and more researchers are of the opinion that recent technological advances offer a level of mobility unseen by modern societies so far, and the support of today's economy and societies depends on maintaining that mobility. They also believe that this type of mobility also generates undesirable effects, especially in densely populated areas. We all agree that greater priority must be given to public transport in metropolitan areas, and the road network is still an important part of daily transport and should be planned and managed with great care.

Today there are studies that propose an optimization methodology that would help traffic authorities better predict the outcome of strategic management decisions in a realistic traffic model. Some propose a multilevel traffic optimization model with a sustainable perspective where the top level of the proposed model considers traffic management strategies, while the lower level takes into account traffic decision makers. They use as a method the balance of stochastic users (Stochastic User Equilibrium SUE), as the authors of the studies consider that it would allow more realistic results than a deterministic model (Kolak, Feyzioğlu, \& Noyan, 2018).

Beyond traffic optimization methods, research into the concept of "Sustainable transport" was a challenge for researchers as well as for government agencies or other interested entities. So far there is no agreed definition of "sustainable transport", which raises issues during the review of existing literature and the promotion of sustainable transport (Zhou, 2012).

There are researchers who consider that sustainability has different meanings for different people, and in many respects can be considered to have conflicting objectives (eg increasing economic growth towards global equality or declining resource use), and therefore definitions of sustainability are related to the values and value systems of the people who produce them (Toth-Szabo \& Várhelyi, 2012). So sustainability encompasses many different disciplines and has many different decisions (Poor and Lindquist, 2009 apud. Toth-Szabo \& Várhelyi, 2012). There are studies using five systems of sustainable mobility indicators selected by frequency of measurements and availability of the global dataset (Poor and Lindquist, 2009).

The privatization of urban transport services could also involve the introduction of additional indicators by regulatory authorities, particularly in terms of sustainable transport development (Litra, Marcel, and Sorin Burlacu (2014).

Specialty literature calls "triple line" to take into account economic, environmental and social objectives in defining sustainability. (Litmann, 2009 apud. Toth-Szabo \& Várhelyi, 
2012). Environmental objectives are often taken into account in sustainable transport, as urban transport is mainly based on fossil fuels (EEA, 2001, Litman, 2004 apud Kolak et al., 2018).

\section{Results}

According to Sustainable Urban Mobility Plan for 2016-2030 Bucharest - Ilfov, main directions are sharing raceway for all road users: motorized bicycles and pedestrians; while reducing the speed of movement. Best practices are shared by cities such as London, Vienna, Stuttgart, Lons le Saunier (France), etc. In addition to the mobility plan data, we have added some important dimensions for comparability and sustainability as well as the size and size of reference cities.

At the level of Bucharest, in 2007, according to the activity report of RATB, the administration board made available to the public at www.ratb.ro a number of approximately 78 million kilometers, representing over 213 thousand kilometers daily or about 9,000 kilometers per hour or $150 \mathrm{~km}$ per second.

If we refer to the 2016 emission factor methodology of the London Business, Energy and Industrial Division's Emissions Efficiency Unit (Hill, Watson and James, 2016), then with emissions of more than 100 units per passenger kilometer $(101.06 \mathrm{CO} 2,0.06 \mathrm{CH} 4$ and $0.60 \mathrm{~N} 2 \mathrm{O}$ ) shows that more than 15 thousand units of polluting emissions are eliminated in Bucharest every second.

In summary, the circulation program of RATB is presented in table no. 1.

Table no. 1 - Evolution of the main operating indicators achieved in 2017.

\begin{tabular}{|l|l|l|l|l|l|l|l|l|}
\hline $\begin{array}{l}\text { Vehicle } \\
\text { category }\end{array}$ & \multicolumn{2}{l}{$\begin{array}{l}\text { Running } \\
\text { (vehicle km) }\end{array}$} & \multicolumn{2}{l|}{$\begin{array}{l}\text { Circulating park } \\
\text { (vehicles x days) }\end{array}$} & \multicolumn{2}{l|}{ Hours } & \multicolumn{2}{l|}{ Racing } \\
\cline { 2 - 10 } & Achieved & $\%$ & Achieved & $\%$ & Achieved & $\%$ & Achieved & $\%$ \\
\hline trams & 17.939 .111 & 97,29 & 84.727 & 98,87 & 1.346 .462 & 97,74 & 840.141 & 97,32 \\
\hline trolleys & 9.078 .989 & 96,33 & 52.525 & 98,47 & 838.469 & 97,11 & 590.341 & 96,11 \\
\hline buses & 50.878 .733 & 97,47 & 260.913 & 99,35 & 3.863 .169 & 98,45 & 2.398 .062 & 96,83 \\
\hline Total & $\mathbf{7 7 . 8 9 6 . 8 3 3}$ & $\mathbf{9 7 , 3 0}$ & $\mathbf{3 9 8 . 1 6 5}$ & $\mathbf{9 9 , 1 3}$ & $\mathbf{6 . 0 4 8 . 1 0 0}$ & $\mathbf{9 8 , 1 1}$ & $\mathbf{3 . 8 2 8 . 5 4 4}$ & $\mathbf{9 6 , 8 3}$ \\
\hline
\end{tabular}

Source: RATB - Activity Report 2017

In Table 2 we made a series of calculations to highlight the situation of RATB transport operations.

Table 2 - Situation of RATB Transport Operation in 2017

\begin{tabular}{|l|l|l|l|l|l|l|l|l|}
\hline $\begin{array}{l}\text { Vehicle } \\
\text { category }\end{array}$ & $\begin{array}{l}\text { Daily } \\
\text { Km/Vehi } \\
\text { cle }\end{array}$ & $\begin{array}{l}\text { Daily } \\
\text { park } \\
\text { vehicle }\end{array}$ & $\begin{array}{l}\text { Percenta } \\
\text { ge of } \\
\text { total }\end{array}$ & $\begin{array}{l}\text { Annual } \\
\text { Hours / } \\
\text { Vehicle }\end{array}$ & $\begin{array}{l}\text { Hours } \\
\text { per } \\
\text { day / } \\
\text { vehicle }\end{array}$ & $\begin{array}{l}\text { Annual } \\
\text { races / } \\
\text { vehicle }\end{array}$ & $\begin{array}{l}\text { Daily } \\
\text { races } \\
\text { /vehic } \\
\text { le }\end{array}$ & $\begin{array}{l}\text { Averag } \\
\text { e race } \\
\text { length } \\
\text { (km) }\end{array}$ \\
\hline trams & 77.281 & 232 & 21,28 & 5.800 & 16 & 3.619 & 10 & 13,32 \\
\hline trolleys & 63.091 & 144 & 13,19 & 5.827 & 16 & 4.102 & 11 & 10,83 \\
\hline buses & 71.176 & 715 & 65,53 & 5.404 & 15 & 3.355 & 9 & 13,17 \\
\hline Total & $\mathbf{7 1 . 4 0 8}$ & $\mathbf{1 . 0 9 1}$ & $\mathbf{1 0 0}$ & $\mathbf{5 . 5 4 4}$ & $\mathbf{1 5}$ & $\mathbf{3 . 5 1 0}$ & $\mathbf{1 0}$ & $\mathbf{1 2 , 8 8}$ \\
\hline
\end{tabular}

Source: Own calculations based on data in Table 1 
Analyzing the situation in Table 2 we find that most of the transport program (over $65 \%$ ) is made by buses. They also make the lowest number of daily races (9) than the average of 10 races.

An explanation might be that in Bucharest, in recent years, there has been an intense urban development activity. The last decade has seen the largest development of supermarkets and shopping centers with direct impact on street tram (Burlacu, S. \& Stoica, A. 2012). Probably the high share of buses in the RATB fleet was a response to the need for mobility in that period, characterized by traffic deviations and route reorganizations. Buses, through their versatility in traffic, really respond to the challenges of road flexibilities.

From the data provided by RATB (Table 3) we can easily distinguish this fact. The working day park utilization rate in Bucharest is below 65\% with an average slightly above $56 \%$.

Table 3 - Park Usage Coefficient (C.U.P.)

\begin{tabular}{|l|l|l|l|l|l|l|}
\hline \multirow{2}{*}{$\begin{array}{l}\text { Vehicle } \\
\text { category }\end{array}$} & \multicolumn{2}{|l|}{ C.U.P. on working day } & \multirow{2}{*}{$+-\%$} & \multicolumn{2}{l|}{ C.U.P. average } & \multirow{2}{*}{+ \% } \\
\cline { 2 - 3 } \cline { 5 - 6 } & $\mathbf{2 0 1 7}$ & $\mathbf{2 0 1 6}$ & & $\mathbf{2 0 1 7}$ & $\mathbf{2 0 1 6}$ & \\
\hline trams & 52,66 & 50,16 & $+4,94$ & 47,76 & 46,06 & $+3,69$ \\
\hline trolleys & 54,93 & 52,55 & $+4,53$ & 48,45 & 46,92 & $+3,26$ \\
\hline buses & 72,29 & 64,26 & $+12,50$ & 62,32 & 56,36 & $+10,57$ \\
\hline
\end{tabular}

Source: RATB - Activity Report 2017

However, there were some attempts by the municipality to carry out a mobility plan taking into account the models (the Vienna ring) or the good practices of the European capitals. (Burlacu et all. 2013).

From an ecological point of view, buses reported on trams and trolleybuses are the most polluting. Quantification of sustainable development (Rojanschi, V., Bran, F., Grigore, F., \& Ioan, I.,2006) cannot be done without considering elements of economic and environmental management (Rojanschi, V., Bran, F., \& Grigore, F., 2004)., general ecology (Bran, F., \& Ioan, I., 2004). as well as the organization, planning and sustainable development of geographic space (Cândea, M., Bran, F., \& Cimpoeru, I., 2006)..

Today, Sustainable Development is readily recognized and accepted by more and more researchers and stakeholders as a vision for a future where "growth limits" are respected while wealth and welfare continue to grow Thus, the concept of Eco-efficiency is proposed to the business framework extends the core principles of management to environmental issues (Bran, F., Radulescu, C. V., \& Ioan, I., 2011).. Eco-efficiency refers to the environmental impact corresponding to the unit of product or service delivered to consumers. It is important that the impact on the environment can be expressed in terms of resources (materials, energy, water) or emissions of pollutants (various emissions, sewage, solid waste, toxic substances) and urban transport policies cannot bypass this concept.

If we take into account that trolleybuses and trams do not use fossil fuels, so they do not pollute the proximate environment by producing traction energy because they use electric energy, then replacing trolleybuses and / or trams would lead to a pollution reduction of over 7000 of tons of polluting emissions per day (7.193.046,6 CO2, 4.270,56 CH4, 42.705,6 N2O). 
Efficiency, either economic or environmental, can only be measured if the means of transport are functional. The situation of technical defects in terms of the number of kilometers performed is shown in Table 4 and shows a net advantage of buses and trams compared to trolleybuses.

Table 4 - Number of technical defects reported in mill.wheels.km. carried out by the RATB fleet in 2016 and 2017

\begin{tabular}{|l|l|l|l|}
\hline \multirow{2}{*}{$\begin{array}{l}\text { Vehicle } \\
\text { category }\end{array}$} & Number of cases per mil.veh.km. & \multirow{2}{*}{$+-\%$} \\
\cline { 2 - 3 } & $\mathbf{2 0 1 7}$ & $\mathbf{2 0 1 6}$ & \\
\hline trams & 297,95 & 250,17 & $+19,10$ \\
\hline trolleys & 469,33 & 405,03 & $+15,88$ \\
\hline buses & 282,16 & 242,80 & $+16,21$ \\
\hline
\end{tabular}

Source: RATB - Activity Report 2017

A sensitive issue is the number of traffic accidents produced by trams that is relatively double and even triple to other vehicle categories. The situation of personal accidents recorded by RATB in 2016 and 2017 respectively is presented in Table 5.

Table 5 - Situation of people accidents by type of vehicle at RATB in 2016 and 2017

\begin{tabular}{|l|l|l|l|}
\hline \multirow{2}{*}{$\begin{array}{l}\text { Vehicle } \\
\text { category }\end{array}$} & Number of cases per mil.veh.km. & $+-\%$ \\
\cline { 2 - 3 } & $\mathbf{2 0 1 7}$ & $\mathbf{2 0 1 6}$ & \\
\hline trams & 1,11 & 1,33 & $-16,54$ \\
\hline trolleys & 0,33 & 0,34 & $-2,94$ \\
\hline buses & 0,45 & 0,89 & $-49,44$ \\
\hline
\end{tabular}

Source: RATB - Activity Report 2017

We subscribe to the idea that sustainable transport means being both environmentally and economically, but especially responsible and safe.

In order to make recommendations on the choice of sustainable means of transport in large urban agglomerations, we investigated the degree of use of the RATB fleet and its correlation with the number of defects, collisions and the number of road accidents. First, we gathered in a database the information contained in the reports RATB period 2009-2017 (Table 6) and then tried to identify if there is a correlation between them.

Table 6 - Situation of accidents, collisions and malfunctions registered at RATB during 2009-2017

\begin{tabular}{|l|l|l|l|l|l|l|l|l|l|}
\hline Veh. Cat. & \multicolumn{2}{l}{ Trams } & \multicolumn{2}{l}{ Trolleys } & \multicolumn{2}{l|}{ Buses } \\
\hline year & Acc. & Coll. & Dam. & Acc. & Coll. & Dam. & Acc. & Coll. & Dam. \\
\hline $\mathbf{2 0 1 7}$ & 1,11 & 37,52 & 297,95 & 0,33 & 20,27 & 469,33 & 0,45 & 26,02 & 282,16 \\
\hline $\mathbf{2 0 1 6}$ & 1,33 & 31,57 & 250,17 & 0,34 & 17,09 & 405,03 & 0,89 & 25,1 & 242,8 \\
\hline $\mathbf{2 0 1 5}$ & 2,02 & 28,57 & 215,91 & 0,73 & 18 & 417,56 & 1,53 & 22,07 & 207,36 \\
\hline $\mathbf{2 0 1 4}$ & 2,64 & 26,58 & 191,19 & 2,31 & 16,84 & 313,51 & 1,62 & 23,92 & 152,44 \\
\hline $\mathbf{2 0 1 3}$ & 1,89 & 26,16 & 163,43 & 1,13 & 15,37 & 262,02 & 1,52 & 21,87 & 86,2 \\
\hline $\mathbf{2 0 1 2}$ & 2,6 & 27,46 & 93,24 & 2,25 & 17,72 & 285,97 & 1,6 & 26,27 & 93,05 \\
\hline $\mathbf{2 0 1 1}$ & 1,88 & 29,08 & 168,18 & 2,2 & 19,19 & 265,51 & 0,54 & 24,91 & 91,19 \\
\hline $\mathbf{2 0 1 0}$ & 2,21 & 29,94 & 199,98 & 1,91 & 17,47 & 286,02 & 0,93 & 27,13 & 123,2 \\
\hline $\mathbf{2 0 0 9}$ & 2,63 & 29,42 & 179,63 & 1,11 & 17,14 & 238,45 & 0,79 & 26,27 & 102,02 \\
\hline
\end{tabular}

Source: Authors' processing according to the data presented in the $\mathrm{RATB}$ reports 
For each mode of transport, we analyzed the tendency of each item analyzed. The situation is shown in Figure 1.

The functions shown in the figure were determined through the excel application by repeated attempts, keeping those functions that recorded an $\mathrm{R}^{2}$ as close to 1 .

\section{Trams}

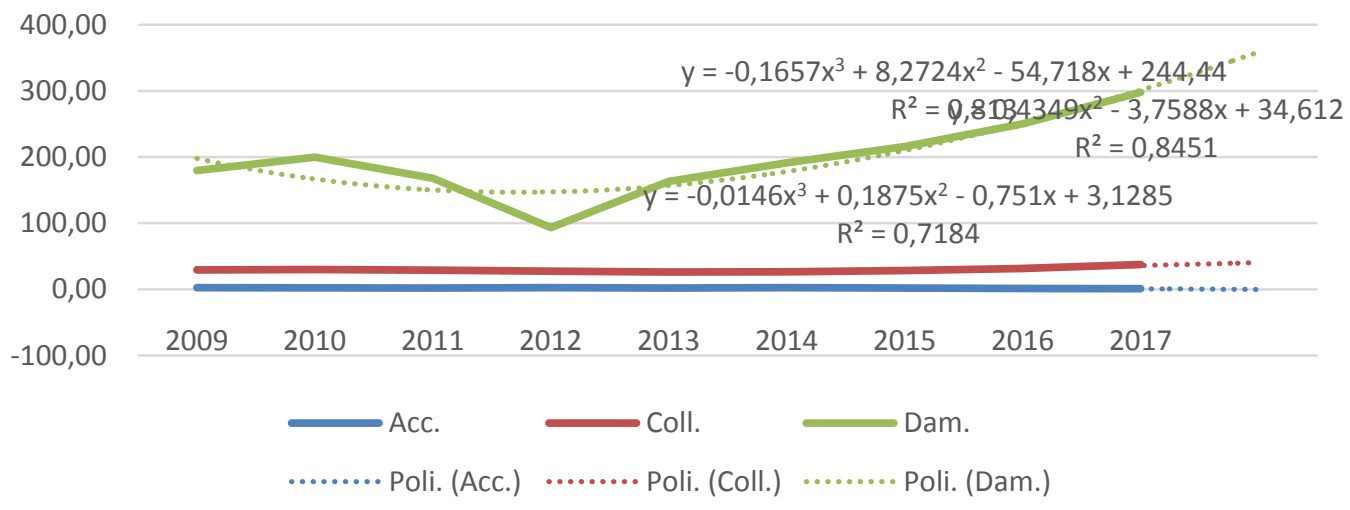

Figure 1 - Highlighting the trend of accidents, collision and malfunctions recorded by trams between 2009-2017 relative to million vebicle kilometers Source: Authors' processing according to data in Table 7

In Figure 2 we highlighted the trend of the elements considered in the analysis for trolleybuses registered during 2009-2017 based on the data provided by RATB.

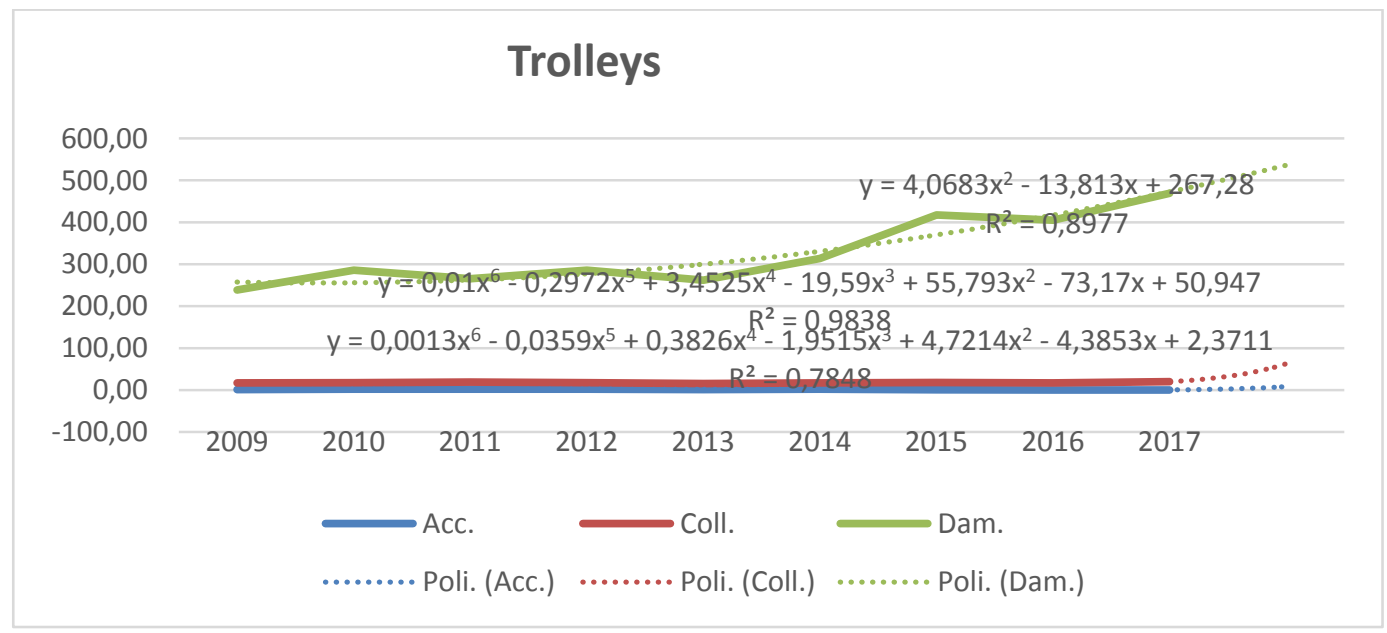

Figure 2 - Highlighting the trend of accidents, collision and damage to trolleys registered in the period from 2009 to 2017 reported in million vebicle kilometers. Source: Authors' processing according to data in Table 7 


\section{Buses}

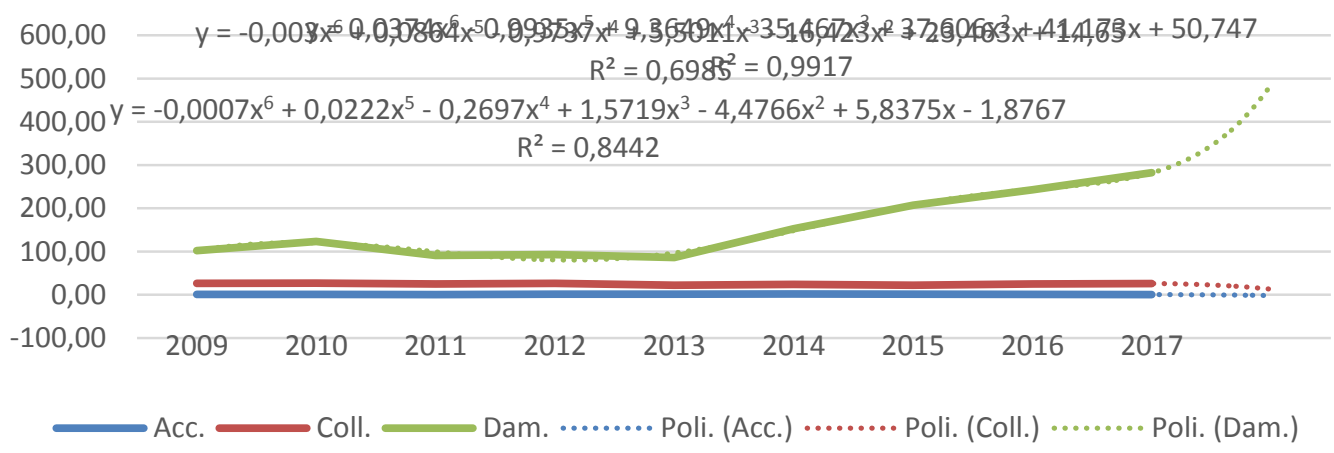

Figure 3 - Highlighting the trend of accidents, collision and damage to buses registered in the period from 2009 to 2017 reported in million vebicle kilometers. Source: Authors' processing according to data in Table 7

The analysis of the obtained functions implies an additional analysis of the factors that would allow the choice of means of transport taking into account these factors.

\section{Conclusions and Recommendations}

Environmental studies suggest that for about 100 liters of consumed diesel, about 1.47 trees need to be planted to re-purify the air. In Bucharest, RATB spends about 90 million lei on the fossil fuel $(90,822$ thousand at the level of 2017), equivalent to over 20 million liters of diesel annually (20,318,000 in 2017 at a reference price of 4.47 lei / liter mid-year), that is more than 54,795 liters every day or 2284 liters per hour; which means that every minute 38 liters are consumed.

We believe that these benefits are closely related to achieving a high-performance traffic management.

The lack of traffic management performed in Bucharest would inevitably lead to the phenomenon of social captivity through the inaccessibility of citizens to transport services with direct consequences on the welfare of the citizen. Trafficking in Bucharest may cause significant problems regarding the access of citizens to the workplace, emergency services, education, social assistance, food, lack of social interaction and recreation, etc.

Proper traffic management can create the right environment for integrated urban regeneration and ensure a diverse and safe social climate. These aspirations would have the effect of increasing the attractiveness of Bucharest for both tourists and investors with direct implications on the quality of life of urban residents.

\section{References}

Bran, F., \& Ioan, I. (2004). Ecologie generală. ASE Publishing.

Bran, F., Radulescu, C. V., \& Ioan, I. (2011). Measures of environmental performance. Review of international comparative management, 12(5), 893-900. 
Burlacu, S. \& Stoica, A. (2012). - Analysis of Freight Transport on the Street Network of Bucharest." Quality-Access to Success 13.

Burlacu, S., Stoica, A., Georgescu, B. C., \& Stoica, S. A. (2013). Basarab Overpass Influence on Road Traffic in the Bucharest Central area. Main Ring Closure Can Come True or is a Utopia?. In Proceedings of Administration and Public Management International Conference (Vol. 9, No. 1, pp. 182-190). Research Centre in Public Administration and Public Services, Bucharest, Romania.

Burlacu, S., \& Stoica, A. (2012). Modern Public Transport. Quality-Access to Success, 13.

Cândea, M., Bran, F., \& Cimpoeru, I. (2006). Organizarea, amenajarea şi dęvoltarea durabilă a spațiului geografic. Universitară Publishing.

EEA (2001). Indicators tracking transport and environment integration in the European Union. Technical report. European Environment Agency.

Hill N., Watson R. and James K. (2016) Government GHG Conversion Factors for Company Reporting: Methodology Paper for Emission Factors.

Kolak, O. İ., Feyzioğlu, O., \& Noyan, N. (2018). Bi-level multi-objective traffic network optimisation with sustainability perspective. Expert Systems with Applications, 104, 294-306. https://doi.org/10.1016/j.eswa.2018.03.034

Litman, T. (2004). Transportation cost and benefit analysis. Technical report. Victoria Transport Policy Institute.

Litmann, T. (2009), Well Measured: Developing Indicators for Comprehensive and Sustainable Transport Planning, Victoria Transport Policy Institute, December 2009

Litra, Marcel, and Sorin Burlacu (2014). Management regulatory liberalization of the public service contracts in the rail industry. Administratie si Management Public 22 (2014): 73.

Poor, A., Lindquits K. (2009) Sustainability and Transportation, Definition and Relationship: Synthesis retrieved on http://www.cmque.com/publications/Sustainmobility2007.pdf

Rojanschi, V., Bran, F., Grigore, F., \& Ioan, I. (2006). Cuantificarea dęuvoltării durabile. Economica Publishing.

Rojanschi, V., Bran, F., \& Grigore, F. (2004). Elemente de economia şi managementul mediului. Economică Publishing.

Toth-Szabo, Z., \& Várhelyi, A. (2012). Indicator Framework for Measuring Sustainability of Transport in the City. Procedia - Social and Behavioral Sciences, 48, 2035-2047. https://doi.org/10.1016/j.sbspro.2012.06.1177.

Zhou, J. (2012). Sustainable transportation in the US: A review of proposals, policies, and programs since 2000. Frontiers of Architectural Research, 1(2), 150-165. https://doi.org/10.1016/j.foar.2012.02.012. 